\title{
Effects of experimentally-impaired reticular contractions on digesta passage in sheep
}

\author{
BY M. KASKE AND A. MIDASCH \\ Department of Physiology, School of Veterinary Medicine, Bischofsholer Damm 15, 30173 Hannover, \\ Germany
}

(Received 20 November 1995 - Revised 4 September 1996 - Accepted 26 November 1996)

\begin{abstract}
The aim of the study was to evaluate the functional role of reticular contractions for digesta passage in sheep. Feed intake, mean retention time of fluid and plastic particles in the reticulo-rumen, rumen fluid volume, forestomach motility and particle size distribution in the faeces were determined in five rumen-fistulated sheep fed on hay ad libitum (Expt 1). The same variables were determined when reticular movements were impaired for $10 \mathrm{~d}$ by introducing a silicone-covered lead weight $(500 \mathrm{~g})$ into the reticulum (Expt 2). As feed intake dropped in Expt 2 by $27 \%$ compared with Expt 1, the sheep received in an additional experiment exactly the amount of feed which had been consumed during Expt 2 and measurements were repeated without impairing reticular movements (Expt 3). The introduction of the weight did not affect the frequency of A- or B-cycles, but elevation of the reticular floor in a cranio-dorsal direction during the biphasic contraction was markedly reduced. The pattern of marker excretion indicated a drastically changed composition of reticular outflow in Expt 2 compared with Expts 1 and 3. During Expt 2, rumen fluid volume was similar to that in Expt 1 but about $25 \%$ higher than that in Expt 3; the amount of large feed particles in the faeces was increased compared with Expt $1(+49 \%)$ and Expt $3(+76 \%)$. In at least two sheep, abomasal emptying was inhibited during Expt 2 , as indicated by an enlarged impacted abomasum. In conclusion, the results emphasize the central role of reticular motility for the separation of particles in the forestomach, the outflow of digesta from the reticulo-rumen and transpyloric digesta flow.
\end{abstract}

Reticulum: Digesta passage rate: Motility: Abomasum

Ruminants achieve an effective microbial degradation of plant-cell-wall constituents by retaining feed particles substantially longer than fluid in the reticulo-rumen (RR; LechnerDoll et al. 1991). Mean retention time (MRT) of particles in the RR depends primarily on particle density and, to a smaller extent, on particle size (Kaske \& Engelhardt, 1990). Density of large feed particles entering the RR is mostly below $1.0 \mathrm{~g} / \mathrm{ml}$ (Sutherland, 1988). Due to rumination and microbial fermentation, particle size decreases (Ulyatt et al. 1986) and particle density increases up to approximately $1.4 \mathrm{~g} / \mathrm{ml}$ (Hooper \& Welch, 1985; Nocek \& Kohn, 1986); MRT of these well-digested dense particles is markedly shorter as compared with freshly-ingested light feed particles (Ehle \& Stern, 1986). Thus, physiological regulation of digesta outflow from the RR requires a separation process within the RR between the portion which is retained from the portion which preferentially leaves the $\mathrm{RR}$ through the reticulo-omasal orifice (ROO). It has been speculated that this separation process is based primarily on the sequence of reticular contractions (Waghorn et al. 1986; Lechner-Doll et al. 1991; Okine \& Mathison, 1991). As outflow from the RR into the omasum occurs predominantly during the second reticular contraction (Mathison et al. 1995), the sequence of the biphasic reticular contraction should also influence the distribution of particles in reticular outflow. 
It was the objective of the present study to investigate the consequences of an experimentally-induced impairment of reticular movements on particle separation processes in the $\mathrm{RR}$ on reticular outflow and on rumino-reticular motility in sheep.

\section{MATERIALS AND METHODS}

\section{Experimental design}

Five rumen-fistulated female Blackhead sheep were used in five experimental periods with three different experimental conditions (Table 1). Sheep had been adapted over several months to an ad libitum diet of hay (g/kg DM: crude fibre 346 (Weende analysis; Nehring, 1960 ), crude protein $(\mathrm{N} \times 6.25) 75$, ash 46$)$. During the experiments animals were kept in metabolism crates. The adaptation period before each experiment was at least $14 \mathrm{~d}$. Sheep received feed four times each day $(08.00,14.00,20.00$ and 02.00 hours). In Expts 1 and 2, animals were fed on $600 \mathrm{~g}$ hay/meal; food refused was weighed and removed before the next feed. In Expt 3, the sheep received each day exactly the amount of hay which had been

Table 1. Experimental design

\begin{tabular}{|c|c|c|c|}
\hline Expt & Duration (d) & Short description & Determined variables \\
\hline $1 \mathrm{~A}$ & 11 & Control ad libitum & $\begin{array}{l}\text { Feed and water intake } \\
\text { Sequence of reticular contractions } \\
\text { MRT }_{\text {GIT }} \text { of plastic particles } \\
\text { MRT }_{\text {dist }} \text { of fluid and plastic particles } \\
\text { MRT }_{\text {RR }} \text { of fluid } \\
\text { Daily duration of feeding, rumination and resting } \\
\text { Rumen fluid volume }\end{array}$ \\
\hline $2 \mathrm{~A}$ & 11 & Weight in reticulum & $\begin{array}{l}\text { Feed and water intake } \\
\text { Sequence of reticular contractions } \\
\text { MRT }_{\text {GrT }} \text { of plastic particles } \\
\text { MRT }_{\text {dist }} \text { of fluid and plastic particles } \\
\text { MRT }_{\mathrm{RR}} \text { of fluid } \\
\text { Daily duration of feeding, rumination and resting } \\
\text { Faecal particle size distribution } \\
\text { Rumen fluid volume }\end{array}$ \\
\hline 3 & 11 & Pair-fed control ${ }^{*}$ & $\begin{array}{l}\text { Feed and water intake } \\
\text { MRT }_{\text {GIT }} \text { of plastic particles } \\
\text { MRT }_{\text {dist }} \text { of fluid and plastic particles } \\
\text { MRT }_{\text {RR }} \text { of fluid } \\
\text { Daily duration of feeding, rumination and resting } \\
\text { Faecal particle size distribution } \\
\text { DM in the RR } \\
\text { Rumen fluid volume }\end{array}$ \\
\hline $1 \mathrm{~B}$ & 11 & Control ad libitum & $\begin{array}{l}\text { Frequency of A- and B-cycles } \\
\text { DM in the RR } \\
\text { Rumen fluid volume } \\
\text { Faecal particle size distribution }\end{array}$ \\
\hline $2 \mathrm{~B}$ & $5,11 \dagger$ & Weight in reticulum & $\begin{array}{l}\text { Frequency of A- and B-cycles } \\
\text { DM in the RR } \\
\text { Rumen fluid volume }\end{array}$ \\
\hline
\end{tabular}

MRT, mean retention time; GIT, gastrointestinal tract; dist, GIT distal to reticulo-rumen; RR, reticulo-rumen.

"Daily feed intake the same as that in Expt 2A.

$\dagger$ Expt 2B was carried out with five sheep; however, for two sheep the experiment was terminated on day 5 due to complications (see p. 100). 
consumed on the respective days during Expt 2A. Water and mineralized salt licks were accessible at all times. Water intake was measured once daily at 08.00 hours.

The weight introduced into the reticulum (Expt 2) was produced by filling a hemispherical mould with a diameter of $100 \mathrm{~mm}$ and a height of $40 \mathrm{~mm}$ with $450 \mathrm{~g}$ melted .Pb. Later, these lead weights were covered completely with a layer of silicone rubber (Efrosil transparent; Frölich, Osterode, Germany). An impervious insulation of the $\mathrm{Pb}$ was achieved by polymerization of the silicone in an autoclave ( $\left.45 \mathrm{~min}, 110^{\circ}, 1.2 \mathrm{bar}\right)$. After introduction into the reticulum, the weight lay cranio-ventrally on the reticular floor; it did not touch the rumino-reticular fold or the ROO during biphasic reticular contractions.

Sonographic investigation. The sequence of reticular contractions was scanned from the left ventral Regio paracondriaca in a cranio-dorsal direction using a mechanical realtime sector scanner (2.5 MHz; Microlmager 1000; Ausonics, Sydney, Australia) on days 2 and 8 of Expt $1 \mathrm{~A}$ (control ad libitum) and Expt 2A (weight in reticulum) respectively. Each sheep was scanned during rest for about 20 min between 10.00 and 12.00 hours. Five to ten biphasic contractions per animal were evaluated from Expt 1A (control ad libitum; a total of forty-three biphasic contractions) and Expt $2 \mathrm{~B}$ (weight in reticulum; a total of thirtyseven contractions). Methodological details have been described recently (Kaske et al. 1994). As no significant differences in the sequence of reticular contractions between days 2 and 8 were found, results of both investigations were averaged.

Marker application for the estimation of the mean retention time in the total gastrointestinal tract $\left(M R T_{G I T}\right)$ and the mean retention time distal to the reticulo-rumen $\left(M R T_{\text {dist }}\right)$. Four mixtures of polyethylene and $\mathrm{BaSO}_{4}$, each with a different dye, were used to produce two sets of plastic particles with a density of $1.03 \mathrm{~g} / \mathrm{ml}$ and two sets of plastic particles with a density of $1.44 \mathrm{~g} / \mathrm{ml}$, according to Kaske \& Engelhardt (1990). All plastic particles were cylindrical with a length of $1 \mathrm{~mm}$ and a diameter of $0.65-0.80 \mathrm{~mm}$.

Markers were administered on day 1 in Expt $1 \mathrm{~A}$ (control ad libitum), on day 2 in Expt $2 \mathrm{~A}$ (i.e. $24 \mathrm{~h}$ after introduction of the weights into the reticulum) and on day 2 in Expt 3 (pair-fed control). For the estimation of $\mathrm{MRT}_{\text {dist }}, 2000$ plastic particles of each density were put in three gelatine capsules ( $4 \mathrm{ml}$; WDT, Hannover, Germany). At 07.30 hours capsules were introduced manually through the ROO and located between the omasal leaves. Immediately after that, a single dose of $15 \mathrm{ml} \mathrm{PEG} \mathrm{(molecular} \mathrm{weight} 4000 ; 250 \mathrm{~g} / \mathrm{l}$; Merck, Darmstadt, Germany) as a fluid marker was administered into the omasum via a plastic tube. To estimate $\mathrm{MRT}_{\mathrm{GIT}}$, at 08.00 hours 10000 plastic particles of both densities mixed with $50 \mathrm{~g}$ ground commercial sheep concentrate were fed to each sheep. Finally, a single injection of CrEDTA $(30 \mathrm{ml}, 10 \mathrm{~g} / \mathrm{f}$; Merck) was introduced as a fluid marker into the RR through the fistula. Samples of rumen fluid were taken 2, 4, 6, 8, 10, 12, 15, 18, 24 and $36 \mathrm{~h}$ after marker administration. Total faecal output was collected on the 1 st day at intervals of $3 \mathrm{~h}$, on the 2nd day at intervals of $6 \mathrm{~h}$ and twice daily at days 3 and 4 . For a second determination of fluid $\mathrm{MRT}_{\text {dist }}$, PEG was administered on day 5 during Expts $1 \mathrm{~A}$, $2 \mathrm{~A}$ and 3; accordingly, faeces were collected on days 5 and 6 at intervals of 3 and $6 \mathrm{~h}$ respectively and twice daily from days 7 to $10 . \mathrm{MRT}_{\mathrm{RR}}$ of fluid was determined three times during Expt 1A (control ad libitum; days 1, 4 and 7), four times during Expt 2A (weight in reticulum; days 2, 4, 6 and 8) and twice during Expt 3 (pair-fed control; days 2 and 8).

Daily duration of feed intake, rumination and rest. This was measured during Expts $1 \mathrm{~A}, 2 \mathrm{~A}$ and 3 in each sheep for $3 \mathrm{~d}$. A rubber tube filled with foam rubber was fixed at the halter of each sheep below the lower jaw. The tube was connected via a polyethylene tube to a pressure transducer (Statham P23Db; H. Sachs, Freiburg, Germany). The typical patterns of pressure changes due to jaw movements during feeding and rumination were recorded (speed of chart paper $10 \mathrm{~mm} / \mathrm{min}$; Watanabe WTR 331 ; H. Sachs). 
Frequency of motility cycles. This was estimated in additional experiments (Expts $1 \mathrm{~B}$ and $2 B$ ) to avoid any disturbance of marker excretion by these measurements. Frequency was recorded in Expts $1 \mathrm{~B}$ and $2 \mathrm{~B}$ for at least 90 min each during feeding, rumination and rest in every animal using the same recording system as described previously. Latex balloons filled with air $(5-10 \mathrm{ml})$ and steel balls (approximately $40 \mathrm{~g}$ ) were placed in the reticulum and the ventral rumen. A third air-filled balloon was placed in the dorsal rumen. Pressure changes due to contractions of the respective compartments of the forestomach were recorded (speed of chart paper $25 \mathrm{~mm} / \mathrm{min}$ ). A contraction cycle of reticulum-dorsal rumen-ventral rumen was regarded as an A-cycle. A contraction of the dorsal rumen followed by a contraction of the ventral rumen was considered as a B-cycle.

Faecal particle size distribution. This was estimated by wet-sieving (four sieves with $100 \mathrm{~mm}$ diameter; pore size 2, $1,0.5$ and $0.25 \mathrm{~mm}$; water flow $800 \mathrm{ml} / \mathrm{min}$ ) on $10 \mathrm{~d}$ during Expt 1B (control ad libitum), on $17 \mathrm{~d}$ before, during and after Expt $2 \mathrm{~A}$ (weight in reticulum) and on $4 \mathrm{~d}$ during Expt 3 (pair-fed control). Faeces samples were taken from the Ampulla recti between 16.00 and 18.00 hours. Three subsamples $(8-10 \mathrm{~g})$ were used for determination of faecal DM. Another three subsamples (2-3 g) were soaked in $500 \mathrm{ml}$ tap water for $12 \mathrm{~h}$. Thereafter, the sample was poured onto the top sieve and sieved for $5 \mathrm{~min}$. The material retained on each sieve was transferred into a glass bowl, dried at $80^{\circ}$ for $24 \mathrm{~h}$ and weighed. The amount of material retained was expressed as $\mathrm{g} / \mathrm{kg}$ total $\mathrm{DM}$ in the subsample.

$D M$ in the reticulo-rumen. This was determined by emptying the forestomach completely through the fistula on the last day of Expts $1 \mathrm{~B}, 2 \mathrm{~B}$ and 3 at 08.00 hours, with the exception of two sheep whose RR was emptied on day 5 during Expt $2 B$ (see p. 102). Total rumen contents were weighed. Three subsamples (150-250 g) were taken for DM determination and the remaining contents were put back into the RR.

Rumen fluid volume. This was determined (a) by subtraction, as the weight of total rumen contents minus DM in the RR, and (b) by dividing the amount of CrEDTA applied to determine the MRT in the RR (MRT $\mathrm{RR}$ ) of fluid by its concentration at time zero using regression analysis.

\section{Analyses}

Faeces were dried for $36 \mathrm{~h}$ at $100^{\circ}$ for determination of DM. A subsample of $200 \mathrm{~g} / \mathrm{kg}$ each was taken from all samples of days 1-3 and from one collection period per $d$ of days 4-10. Subsamples were ground in a coffee grinder (K6; Bosch, Stuttgart, Germany) and sieved through a $500 \mu \mathrm{m}$ wire-mesh sieve (Retsch, Haan, Germany). Plastic particles in each subsample were manually separated from the remaining faecal particles, sorted according to their density by colour, and weighed. The concentration of plastic particles was calculated for each density as the number of particles per $g$ faecal DM; for that, the weight of particles found in the respective sample was divided by the mean weight of one uncomminuted particle of the respective density.

PEG in the respective faeces subsamples was analysed as described by Hydén (1955); $\mathrm{Cr}$ concentration in rumen fluid samples was determined according to Binnerts et al. (1968).

\section{Calculations}

MRT $_{\text {GIT }}$ of plastic particles and MRT $\mathrm{Mist}_{\text {did }}$ of fluid and particles were calculated according to Thielemans et al. (1978): $\mathrm{MRT}=\left(\sum c_{t} \times t \times d t\right) /\left(\sum c_{t} \times d t\right)$, where $c_{t}$ is the marker 
concentration in the sample, $t$ is the time-interval after marker administration at which the sample was taken, and $d t$ is the faecal collection interval. Total faecal recovery of particle markers during the $10 \mathrm{~d}$ collection period varied between 67.7 and $95.2 \%$.

$\mathrm{MRT}_{\mathrm{RR}}$ of plastic particles was calculated as $\mathrm{MRT}_{\mathrm{GrT}}-\mathrm{MRT}_{\text {dist }} \cdot \mathrm{MRT}_{\mathrm{RR}}$ of fluid was calculated as $\mathrm{MRT}_{\mathrm{RR}}=k^{-1}$ from the equation $k=\left(\ln c_{o}-\ln c_{t}\right) \times t^{-1}$, where $c_{o}$ is the marker concentration at zero time calculated by regression analysis and $c_{t}$ is the marker concentration at sampling time $t$.

Fluid outflow from the RR (1/h) in Expts $1 \mathrm{~A}, 2 \mathrm{~A}$ and 3 was calculated as rumen fluid volume divided by $\mathrm{MRT}_{\mathrm{RR}}$ of fluid. The number of openings of the ROO per d during the respective experiments was estimated as: $\left(F \times D_{\text {Feeding }}\right)+\left(F \times D_{\text {Rumination }}\right)+\left(F \times D_{\text {Rest }}\right)$, where $F$ is the frequency of A-cycles and $D$ is the daily duration of the respective activity. Frequency values determined in Expt 1B were also applied for Expt 3. Fluid outflow from the RR per opening of the ROO was calculated as rumen outflow per day divided by the number of ROO-openings per day.

\section{Statistics}

SIGMASTAT (Jandel Corporation, 1993) was used for statistical appraisal of the results which are presented as means with their standard errors. The significance of differences at a level of $P<0.05$ was tested using ANOVA for repeated measurements followed by a Student-Newman-Keuls Test for multiple comparisons. Additionally, a paired $t$ test over all animals was carried out to calculate the significance level of actual changes.

\section{RESULTS}

The weight in the reticulum did not influence the frequency of A- and B-cycles; also the duration of both reticular contractions was not markedly affected (Table 2). However, the sonographic investigation indicated that the sequence of reticular contractions was drastically influenced. Due to the weight, the reticular floor moved during the biphasic contraction only $10-30 \mathrm{~mm}$ in a cranio-dorsal direction (Table 2); this was an exceptional reduction especially for the second reticular contraction compared with undisturbed reticular contractions. After introduction of the weight, the velocity with which the reticular floor moved cranio-dorsally was reduced by $60-80 \%$ (for details relating to the evaluation of sonographic recordings, see Kaske et al. 1994). Although the reticular floor was only slightly elevated during the reticular contractions, clear biphasic contractions of the reticular wall were recognizable.

After introduction of the weight into the reticulum (Expt 2A) the mean feed intake dropped significantly $(P=0.044)$, by $390 \mathrm{~g}$ on average compared with Expt $1 \mathrm{~A}$ (control ad libitum; Table 3); the mean water intake decreased by 1.7 litres $(P<0.001)$. Feed intake remained on a lower level but returned to the initial values immediately after removal of the weight from the reticulum (Fig. 1(A)). However, the animals did not react uniformly to the weight in the reticulum; intake decreased in three animals by only 10-20\% but in the other two sheep by about $50 \%$. When the weight was introduced again into the reticulum (Expt 2B), feed intake of these latter two animals declined from day 1 to day 4 to nearly zero; thus, the experimental period ended on day 5 in these two sheep. The reduction in feed intake in the other sheep during Expt 2B was comparable with that during Expt 2A.

The composition of forestomach contents was directly observed during rumen emptying. Rumen contents were well-stratified and firm during periods of ad libitum feeding (Expt 1), but appeared mixed and viscous after introduction of the weights into the 
Table 2. Characteristics of reticular contractions determined by sonographic investigation and frequency of $A$ - and $B$-cycles as estimated by recording pressure differences in balloons placed in the reticulum, dorsal and ventral rumen sac during the control period and after introduction of a weight $(500 \mathrm{~g})$ into the reticulum of sheep ${ }^{*}$

(Mean values with their standard errors for five sheep)

\begin{tabular}{|c|c|c|c|c|}
\hline & \multicolumn{2}{|c|}{$\begin{array}{l}\text { Expts } 1 \mathrm{~A} \text { and } 1 \mathrm{~B} \\
\text { (control ad libitum) }\end{array}$} & \multicolumn{2}{|c|}{$\begin{array}{c}\text { Expts } 2 \mathrm{~A} \text { and } 2 \mathrm{~B} \\
\text { (weight in reticulum) }\end{array}$} \\
\hline & Mean & SE & Mean & SE \\
\hline \multicolumn{5}{|l|}{ Reticular contractions } \\
\hline \multicolumn{5}{|l|}{ First contraction } \\
\hline Total durationt (s) & $2 \cdot 16^{\mathrm{a}}$ & $0 \cdot 11$ & $2 \cdot 55^{\mathrm{b}}$ & 0.08 \\
\hline Contraction distancef $(\mathrm{mm})$ & $53^{\mathrm{a}}$ & 7 & $26^{\mathrm{b}}$ & 3 \\
\hline \multicolumn{5}{|l|}{ Second contraction } \\
\hline Total durationt (s) & $2 \cdot 80^{\mathrm{a}}$ & 0.15 & $2.74^{\mathrm{a}}$ & 0.09 \\
\hline Contraction distance $\ddagger(\mathrm{mm})$ & $>100 \S$ & & 25 & 7 \\
\hline \multicolumn{5}{|l|}{ Forestomach motility $\|$} \\
\hline \multicolumn{5}{|l|}{ A-cycles $(/ \mathrm{min})$} \\
\hline During feeding & $1.86^{\mathrm{a}}$ & 0.07 & $1.96^{\mathrm{a}}$ & 0.08 \\
\hline During rumination & $1 \cdot 16^{\mathrm{a}}$ & 0.03 & $1 \cdot 25^{\mathrm{a}}$ & 0.07 \\
\hline During rest & $1.08^{\mathrm{a}}$ & 0.07 & $0.98^{\mathrm{a}}$ & 0.06 \\
\hline \multicolumn{5}{|l|}{ B-cycles (/min) } \\
\hline During feeding & $1 \cdot 01^{\mathrm{a}}$ & 0.06 & $0 \cdot 83^{\mathrm{a}}$ & $0 \cdot 10$ \\
\hline During rumination & $0.65^{\mathrm{a}}$ & 0.04 & $0.65^{\mathrm{a}}$ & 0.05 \\
\hline During rest & $0.58^{\mathrm{a}}$ & 0.05 & $0.47^{\mathrm{a}}$ & 0.11 \\
\hline
\end{tabular}

${ }^{a . b}$ Mean values with unlike superscript letters in the same horizontal row were significantly different $(P<0.05)$.

* For details of experimental procedures, see pp. 98-100.

$\dagger$ Starting with the first movement of the rumino-reticular fold until the reticular floor reaches its most ventral position.

$\ddagger$ Distance between the starting point and the most dorsal position of the reticular floor.

$\S$ The reticular floor disappeared from the screen in a dorsal direction; thus, no precise contraction distance could be determined.

|| Frequency of forestomach motility remained unaffected by the weight.

reticulum (Expt 2). In contrast, on the same level of feed intake but without impaired reticular movements (Expt 3), forestomach contents became progressively more watery. The total amount of DM in the RR was reduced in Expt 2B (weight in reticulum) compared with Expt 1B (control ad libitum; Table 3; $P=0.048$ ); no significant difference was found for the amount of DM between Expt 2B and Expt 3 (pair-fed control).

The duration of feeding was reduced during Expt $2 \mathrm{~A}$ compared with Expt $1 \mathrm{~A}$ $(P=0.023)$. However, when no weight was present in the reticulum and the same amounts of hay were consumed (Expt 3; pair-fed control), feed intake occurred in less than half the time. Rumination activity did not vary significantly between Expts 1A, 2A and 3 (Table 3).

Compared with Expt 1A (control ad libitum), $\mathrm{MRT}_{\mathrm{RR}}$ of fluid was increased by $2.6 \mathrm{~h}$ after introduction of the weights (Expt 2A; $P=0.048$ ). Results of repeated measurements did not vary significantly, indicating a steady-state existed under both experimental conditions. In contrast, no steady-state was found in Expt 3 (pair-fed control); fluid was retained progressively longer in the RR than in Expt 1A and 2A (Table 4).

Despite differences in feed intake, rumen fluid volume was similar in Expt 2A (weight in reticulum) and Expt $1 \mathrm{~A}$ (control ad libitum; Table 3). By contrast, the rumen fluid volume of sheep with the same intake as that during Expt $2 \mathrm{~A}$ but undisturbed reticular movements (Expt 3$)$ decreased significantly $(P=0.022)$ by about 3 litres compared with ad 
Table 3. Intake of feed and water, rumen fluid volume, DM in the reticulo-rumen and duration of different activities during the control experiment with ad libitum intake (Expt 1), after impairment of reticular movements due to a weight $(500 \mathrm{~g})$ introduced into the reticulum (Expt 2) and during an additional control experiment (Expt 3) when sheep received the amount of hay which was consumed during Expt $2 A^{*}$

(Mean values with their standard errors for five sheep)

\begin{tabular}{|c|c|c|c|c|c|c|}
\hline & \multicolumn{2}{|c|}{$\begin{array}{l}\text { Expt } 1 \mathrm{~A} \text { and } 1 \mathrm{~B} \\
\text { (control ad libitum) }\end{array}$} & \multicolumn{2}{|c|}{$\begin{array}{c}\text { Expt } 2 \mathrm{~A} \text { and } 2 \mathrm{~B} \\
\text { (weight in reticu- } \\
\text { lum) }\end{array}$} & \multicolumn{2}{|c|}{$\begin{array}{c}\text { Expt } 3 \\
\text { (pair-fed control) }\end{array}$} \\
\hline & Mean & $\mathrm{SE}$ & Mean & SE & Mean & SE \\
\hline Body wt $\dagger(\mathrm{kg})$ & $63 \cdot 1^{a}$ & $2 \cdot 3$ & $61 \cdot 7^{\mathrm{a}}$ & 2.8 & $57 \cdot 0^{\mathrm{b}}$ & $3 \cdot 3$ \\
\hline Feed intake $\dagger(\mathrm{g} / \mathrm{d})$ & $1430^{\mathrm{a}}$ & 125 & $1040^{\mathrm{b}}$ & 184 & $1020^{\mathrm{b}}$ & 163 \\
\hline Water intake $\dagger^{\dagger}(1 / d)$ & $4.4^{\mathrm{a}}$ & 0.2 & $2 \cdot 7^{\mathrm{b}}$ & 0.4 & $2 \cdot 2^{\mathrm{b}}$ & 0.7 \\
\hline Rumen fluid volumet (1) & $13 \cdot 0^{\mathbf{a}}$ & 0.6 & $12 \cdot 1^{\mathrm{a}}$ & 0.7 & $9.9^{\mathrm{b}}$ & 0.6 \\
\hline Rumen fluid volume§ (1) & $12 \cdot 0^{\mathrm{a}}$ & 0.7 & $11.7^{\mathrm{a}}$ & 0.7 & $8 \cdot 6^{\mathrm{b}}$ & 0.6 \\
\hline DM in reticulo-rumen $\S(\mathrm{g})$ & $1351^{\mathrm{a}}$ & 74 & $956^{\mathrm{b}}$ & 158 & $736^{\mathrm{b}}$ & 63 \\
\hline \multicolumn{7}{|l|}{ Duration $(\mathrm{min} / \mathrm{d})$ of: } \\
\hline Feeding $\dagger$ & $461^{a}$ & 13 & $382^{b}$ & 22 & $159^{c}$ & 20 \\
\hline Rumination $\uparrow$ & $548^{\mathrm{a}}$ & 34 & $515^{\mathrm{a}}$ & 60 & $492^{\mathrm{a}}$ & 27 \\
\hline Rest $†$ & $431^{\mathrm{a}}$ & 37 & $543^{\mathrm{a}}$ & 61 & $789^{\mathrm{b}}$ & 36 \\
\hline
\end{tabular}

${ }^{\mathrm{a}, \mathrm{b}}$ Mean values with unlike superscript letters in the same horizontal row were significantly different $(P<0 \cdot 05)$.

* For details of experimental procedures, see pp. 98-100.

$\dagger$ Determined in Expts 1A, 2A and 3.

$\ddagger$ Determined indirectly by using CrEDTA in Expts $1 \mathrm{~A}, 2 \mathrm{~A}$ and 3 .

$\S$ Determined directly after emptying the reticulo-rumen in Expts $1 \mathrm{~B}, 2 \mathrm{~B}$ and 3.

libitum-fed sheep (Expt 1A). Thus, rumen fluid volume was increased relative to feed intake after introduction of the weight into the reticulum. Rumen fluid volumes did not differ significantly between Expts $2 \mathrm{~A}$ and $2 \mathrm{~B}$. Rumen outflow was significantly reduced in Expt 2A compared with Expt 1A $(P=0.015$; Table 5). The number of openings of the ROO perd was similar during Expts $1 \mathrm{~A}$ and $2 \mathrm{~A}$; however, fluid outflow per opening of the ROO was reduced $(P=0.042)$ after introduction of the weight compared with ad libitum feeding with undisturbed reticular movements (Expt 1A). Towards the end of Expt 3 (pairfed control), rumen fluid volume and rumen outflow perh and per opening of the ROO were even less than those in Expt $2 \mathrm{~A}$ (weight in reticulum).

When reticular contractions were unaffected (Expt $1 \mathrm{~A}$ and 3), $\mathrm{MRT}_{\mathrm{RR}}$ of plastic particles with a low density $(1.03 \mathrm{~g} / \mathrm{ml})$ were approximately three to four times longer than $\mathrm{MRT}_{\mathrm{RR}}$ of heavy particles $(1.44 \mathrm{~g} / \mathrm{ml})$, i.e. light particles were selectively retained in the RR while dense particles left the forestomach preferentially. The level of feed intake influenced the $\mathrm{MRT}_{\mathrm{RR}}$ of light particles which was significantly longer during restricted feeding (Expt 3) compared with ad libitum feeding (Expt $1 \mathrm{~A} ; P=0.047$ ). Introduction of the weight into the reticulum induced drastic changes in particle marker excretion (Table 4). $\mathrm{MRT}_{\mathrm{RR}}$ of heavy particles was more than four times longer compared with Expt 1A or Expt $3(P=0.008)$. Values for $\mathrm{MRT}_{\mathrm{RR}}$ of plastic particles with a low density did not vary between Expts $1 \mathrm{~A}$ and $2 \mathrm{~A}$; however, after introduction of the reticular weight these particles were retained in the RR for a significantly shorter period $(P=0.021)$ compared with that measured during undisturbed reticular contractions and a comparable level of feed intake (Expt 3).

Sieve analysis of the faeces revealed that the composition of reticular outflow changed after the introduction of the weight into the reticulum. Large feed particles were less 


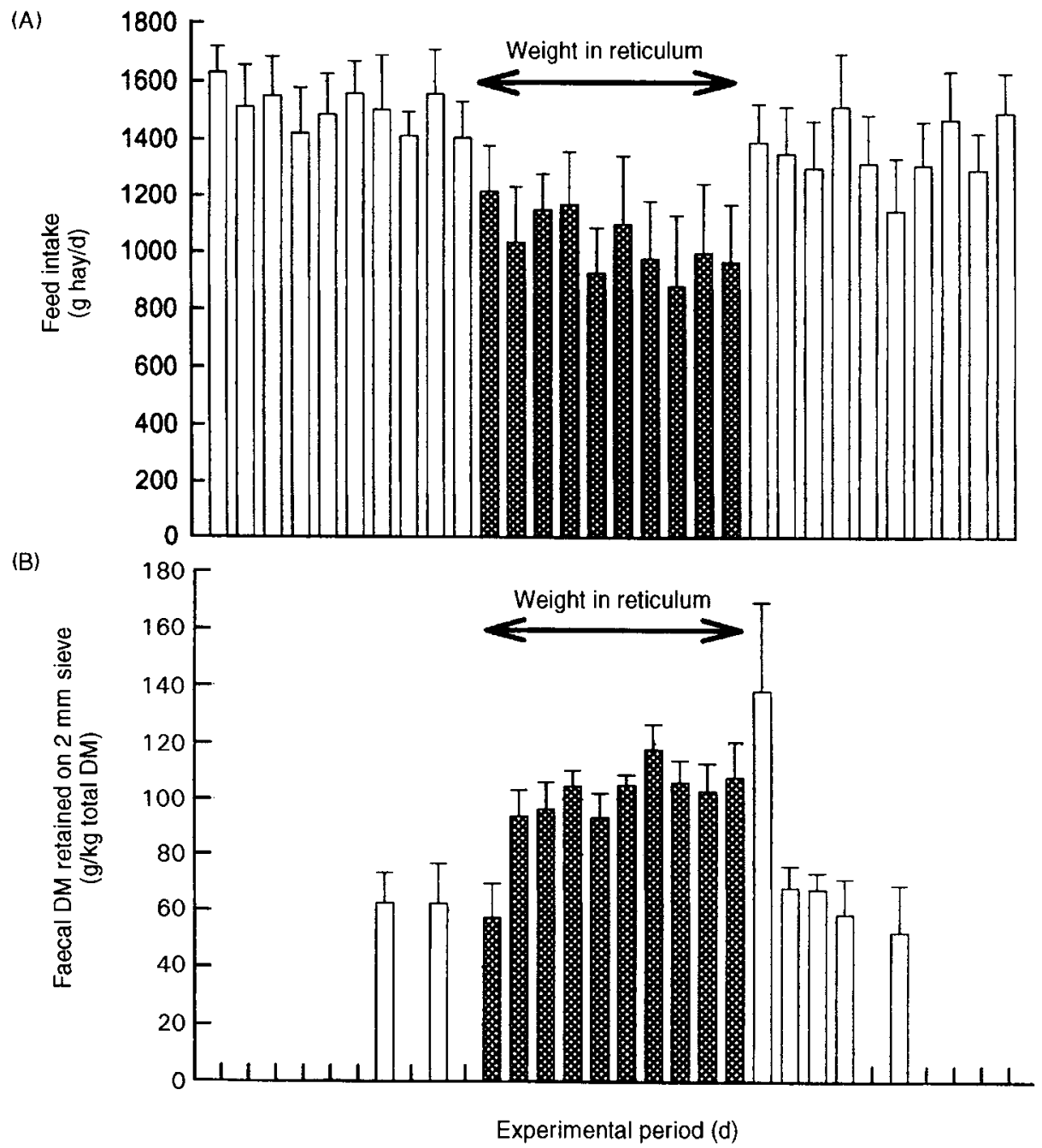

Fig. 1. (A) Changes of feed intake and (B) portion of faecal dry matter retained on a sieve with a pore size of $2 \mathrm{~mm}$ due to the introduction of a weight $(500 \mathrm{~g})$ into the reticulum of sheep (Expt $2 \mathrm{~A})$. Values are means with their standard errors represented by vertical bars for five sheep for $1 \mathrm{~d}$. For details of experimental procedures, see pp. 98-100.

effectively retained in the $\mathrm{RR}$ in Expt $2 \mathrm{~A}$ (weight in reticulum), as indicated by an increased proportion of large particles in the faeces compared with Expt 1A (control ad libitum; $P=0.021$ ) or Expt 3 (pair-fed control; $P=0.017$; Table 4). When the weight was added the amount of DM on the sieve with $2 \mathrm{~mm}$ pore size was almost doubled compared with the period before and after the introduction of the weight (Fig. 1(B)). Correspondingly, the proportion of small particles in the faeces was reduced when the weight was present in the reticulum compared with Expt 1A $(P=0.013$; Table 4). The smallest proportion of large particles and the highest proportion of small particles was found in Expt 3 (pair-fed control). 
Table 4. Mean retention time (MRT) of fluid and plastic particles in the reticulo-rumen (RR; $\left.M R T_{R R}\right)$ and distal to the $R R\left(M R T_{\text {dist }}\right)$ and faecal particle size distribution as determined by wet sieving during the control experiment with ad libitum intake (Expt 1), after impairment of reticular contractions due to a weight $(500 \mathrm{~g})$ introduced into the reticulum (Expt 2) and during an additional control experiment (Expt 3) when sheep received the amount of hay which was consumed during Expt $2 A^{*}$

(Mean values with their standard errors for five sheep)

\begin{tabular}{|c|c|c|c|c|c|c|}
\hline & \multicolumn{2}{|c|}{$\begin{array}{l}\text { Expt } 1 \mathrm{~A} \text { and } 1 \mathrm{~B} \\
\text { (control } a d \text { libitum) }\end{array}$} & \multicolumn{2}{|c|}{$\begin{array}{c}\text { Expt 2A } \\
\text { (weight in reticulum) }\end{array}$} & \multicolumn{2}{|c|}{$\begin{array}{c}\text { Expt } 3 \\
\text { (pair-fed control) }\end{array}$} \\
\hline & Mean & $\mathrm{SE}$ & Mean & $\mathrm{SE}$ & Mean & SE \\
\hline \multicolumn{7}{|l|}{$\mathrm{MRT}_{\mathrm{RR}} \dagger(\mathrm{h})$} \\
\hline Fluid & $9.8^{\mathrm{a}}$ & 0.5 & $12 \cdot 4^{\mathrm{b}}$ & $1 \cdot 3$ & $16 \cdot 3^{\mathrm{c}}$ & $1 \cdot 3$ \\
\hline \multicolumn{7}{|l|}{ Particles } \\
\hline $1 \mathrm{~mm}, 1.03 \mathrm{~g} / \mathrm{ml}$ (a) & $38 \cdot 4^{\mathrm{a}}$ & $2 \cdot 2$ & $42 \cdot 3^{a}$ & $5 \cdot 6$ & $55 \cdot 6^{\mathrm{b}}$ & $7 \cdot 6$ \\
\hline $1 \mathrm{~mm}, 1.44 \mathrm{~g} / \mathrm{ml}(\mathrm{b})$ & $14 \cdot 7^{\mathrm{a}}$ & $2 \cdot 1$ & $62 \cdot 5^{\mathrm{b}}$ & 9.6 & $13 \cdot 6^{\mathrm{a}}$ & 3.6 \\
\hline$a: b$ & $2.9^{\mathrm{a}}$ & 0.5 & $0.8^{\mathrm{b}}$ & $0 \cdot 1$ & $4.9^{\mathrm{a}}$ & 0.9 \\
\hline \multicolumn{7}{|l|}{$\mathrm{MRT}_{\text {dist }} \ddagger(\mathrm{h})$} \\
\hline Fluid & $16 \cdot 2^{\mathrm{a}}$ & 0.7 & $19 \cdot 4^{\mathrm{b}}$ & $2 \cdot 0$ & $19 \cdot 3^{b}$ & 1.8 \\
\hline \multicolumn{7}{|l|}{ Particles } \\
\hline $1 \mathrm{~mm}, 1.03 \mathrm{~g} / \mathrm{ml}(\mathrm{a})$ & $19 \cdot 4^{\mathrm{a}}$ & 1.8 & $22 \cdot 4^{\mathrm{b}}$ & $2 \cdot 6$ & $20 \cdot 5^{\mathrm{ab}}$ & $2 \cdot 0$ \\
\hline $1 \mathrm{~mm}, 1.44 \mathrm{~g} / \mathrm{ml}$ (b) & $52 \cdot 6^{\mathrm{a}}$ & $5 \cdot 4$ & $44.9^{b}$ & 9.5 & $39 \cdot 3^{\mathrm{b}}$ & 7.7 \\
\hline \multicolumn{7}{|c|}{ Faecal particle size distribution (g/kg DM) } \\
\hline Large particles§ & $98^{\mathrm{a}}$ & 12 & $146^{b}$ & 6 & $83^{c}$ & 14 \\
\hline Small particles $\|$ & $505^{\mathrm{a}}$ & 13 & $442^{\mathrm{b}}$ & 13 & $537^{\mathrm{C}}$ & 9 \\
\hline Rest & $397^{\mathrm{a}}$ & 8 & $412^{\mathrm{a}}$ & 10 & $378^{\mathrm{a}}$ & 9 \\
\hline
\end{tabular}

a,b,c Mean values with unlike superscript letters in the same horizontal row were significantly different $(P<0.05)$.

* For details of experimental procedures, see pp. 98-101.

$\dagger$ Determined by calculation (see p. 101).

\$Determined from faecal marker excretion after introduction of the markers through the reticulo-omasal orifice into the omasum.

$\S \mathrm{DM}$ of the faeces sample retained on sieves with 2.0 and $1.0 \mathrm{~mm}$ pore size.

|| DM of the faeces sample retained on sieves with 0.5 and $0.25 \mathrm{~mm}$ pore size.

DM of the faeces sample which passed the sieve with $0.25 \mathrm{~mm}$ pore size (calculated).

$\mathrm{MRT}_{\text {dist }}$ of fluid and plastic particles were not markedly influenced by the introduction of the weight (Expt 1A $v$. Expt 2A) nor by the level of feed intake (Expt 1A $v$. Expt 3) (Table 4). Although $\mathrm{MRT}_{\text {dist }}$ of light particles was significantly longer in Expt $2 \mathrm{~A}$ compared with Expt $1 \mathrm{~A}(P=0.049)$, the absolute difference was rather small.

When the RR was emptied after Expt $2 B$ (weight in reticulum) an enlarged abomasum was palpated through the rumen wall in all five sheep. Abomasal enlargement was most distinct in the two sheep whose feed intake declined most markedly. The abomasum was filled in the antrum and in the area of the pylorus with a firm mass. Immediately after removing the weight from the reticulum, four sheep started to feed normally and abomasal enlargement disappeared with $2 \mathrm{~d}$. Feed intake of the fifth animal remained negligible during the following $2 \mathrm{~d}$. X-ray analysis revealed massive abomasal impaction. Thus, a laparotomy was performed and the abomasum was emptied; $2.2 \mathrm{~kg}$ of a firm mass interspersed with large feed particles was removed. Within the next $3 \mathrm{~d}$ the general condition and feed intake of the sheep improved and the animal recovered completely. 
Table 5. Characteristics of fluid outflow through the reticulo-omasal orifice (ROO) during the control experiment with ad libitum intake (Expt 1), after impairment of reticular contractions due to a weight $(500 \mathrm{~g})$ introduced into the reticulum (Expt 2) and during an additional control experiment (Expt 3) when sheep received the amount of hay which had been consumed during Expt $2^{*}$

(Mean values with their standard errors for five sheep)

\begin{tabular}{|c|c|c|c|c|c|c|c|c|}
\hline & \multirow{2}{*}{\multicolumn{2}{|c|}{$\begin{array}{c}\text { Expts } 1 \mathrm{~A} \text { and } 1 \mathrm{~B} \\
\text { (control ad libi- } \\
\text { tum) }\end{array}$}} & \multirow{2}{*}{\multicolumn{2}{|c|}{$\begin{array}{c}\text { Expt } 2 \mathrm{~A} \\
\text { (weight in reticu- } \\
\text { lum) }\end{array}$}} & \multicolumn{4}{|c|}{$\begin{array}{c}\text { Expt } 3 \\
\text { (pair-fed control) } \ddagger\end{array}$} \\
\hline & & & & & \multicolumn{2}{|c|}{ Day 2} & \multicolumn{2}{|c|}{ Day 8} \\
\hline & Mean & SE & Mean & SE & Mean & SE & Mean & SE \\
\hline Rumen outflowt (l/h) & $1.35^{\mathrm{a}}$ & 0.11 & $1.04^{b}$ & 0.15 & $0.81^{\mathrm{b}}$ & 0.08 & $0.59^{\mathrm{c}}$ & 0.08 \\
\hline Openings of the ROO $\$(/ d)$ & $1957^{\mathrm{a}}$ & 44 & $1927^{\mathrm{a}}$ & 63 & \multicolumn{2}{|c|}{$1716^{\mathrm{b}}$} & \multicolumn{2}{|c|}{61} \\
\hline Fluid fow per opening $\|(\mathrm{ml})$ & $16 \cdot 6^{\mathrm{a}}$ & 1.9 & $12.9^{b}$ & $2 \cdot 0$ & $11 \cdot 6^{\mathrm{b}}$ & 1.4 & $8 \cdot 3^{\mathrm{c}}$ & $1 \cdot 2$ \\
\hline
\end{tabular}

${ }^{a, b, c}$ Mean values with unlike superscript letters in the same horizontal row were significantly different $(P<0.05)$.

ROO, reticulo-omasal orifice.

* For details of experimental procedures, see pp. 98-101.

$\dagger$ Calculated as rumen fluid volume divided by mean retention time in reticulo-rumen of fluid.

$\ddagger$ Steady-state conditions had been proved for Expts $1 \mathrm{~A}$ and 2A, but not for Expt 3; thus, values of both determinations on days 2 and 8 are presented, except for openings of the ROO.

$\S$ Calculated from the duration of feeding, rumination and rest and the frequency of A-cycles.

$\|$ Calculated as rumen outflow per d divided by the number of ROO openings per $d$.

\section{DISCUSSION}

\section{Characteristics of digesta passage during control experiments}

The results of the experiments with undisturbed reticular movements (Expts 1 and 3) indicate, in agreement with other studies (for example, DesBordes \& Welch, 1984; Ehle \& Stern, 1986; Kaske \& Engelhardt, 1990), that particles with a low density are retained longer in the RR than dense particles. A prolonged $\mathrm{MRT}_{\mathrm{RR}}$ of fluid and light plastic particles due to reduced feed intake (Expt $3 v$. Expt 1A) reflects the well-known effect of intake on rumen outflow (for example, Mudgal et al. 1982; Faichney \& Gherardi, 1986). A significantly longer MRT of dense particles distal to the RR compared with fluid and light particles has been described previously (Campling \& Freer, 1962; Siciliano-Jones \& Murphy, 1986; Kaske \& Engelhardt, 1990).

\section{Consequences of experimentally-impaired reticular movements}

In sheep fed on $1020 \mathrm{~g}$ lucerne (Medicago sativa) chaff/d, the reticulum is filled with 550$750 \mathrm{~g}$ digesta (Waghorn et al. 1986) which are moved during the reticular contractions in a dorso-caudal direction with a velocity of approximately $50 \mathrm{~mm} / \mathrm{s}$ (Kaske et al. 1994). The introduction of the weight $(500 \mathrm{~g})$ into the reticulum almost doubled the reticular load. The changes observed thereafter may be influenced by the excitation of tension receptors in the reticular wall by the weight present in the reticulum; the activation of these receptors could have triggered inhibitory reflexes mediated by vago-vagal pathways. However, the 
frequency of reticular and rumen contractions was not affected at all by the weight. Second, sonographic investigation indicated that the total duration of both reticular contractions was not markedly altered by the weight, and even the region of the reticulum mostly affected by the weight was able to contract. Although weight-induced reflexes might have modulated the amplitude of rumen motility, we believe that the changes observed in Expt 2 were caused predominantly by the reduced amplitude of reticular movements due to direct effects of the weight.

The results of marker excretion and sieve analysis of faeces indicated a drastic change in the composition of reticular outflow due to impaired reticular movements. The ratio $\mathrm{MRT}_{\mathrm{RR}}$ of light plastic particles : $\mathrm{MRT}_{\mathrm{RR}}$ of dense plastic particles (Table 4) indicates that the selective retention of light particles under control conditions (Expts 1 and 3) was abolished by impairing the sequence of reticular contractions (Expt $2 \mathrm{~A}$ ). The prolonged $\mathrm{MRT}_{\mathrm{RR}}$ of dense particles was most probably caused by a reduced rate of passage of these particles during each opening of the ROO. Since the weight prevented the normal elevation of the reticular floor in a cranio-dorsal direction up to the level of the ROO, it is suggested that dense plastic particles remained in the reticular cells during the opening of the ROO. The reduced amount of small particles in the faeces of sheep during Expt 2 (weight in reticulum) reflects the same phenomenon, as the density of such small particles is predominantly high (Evans et al. 1973; Sutherland, 1988). A reduced transport of small dense particles from the rumen into the reticulum cannot explain the increased $\mathrm{MRT}_{\mathrm{RR}}$ of these particles, as the frequency of forestomach motility was not affected by the weight. Furthermore, an artificial effect due to entrapment of sedimented dense particles in the reticulum by the weight can be largely excluded since the weight lay cranio-ventrally in the reticulum and covered less than one-third of the reticular floor.

The shorter $\mathrm{MRT}_{\mathrm{RR}}$ of light plastic particles during Expt $2 \mathrm{~A}$ (weight in reticulum) compared with Expt 3 (pair-fed control) reveals that passage of these particles through the ROO is normally prevented by the reticular contractions which push them in a caudal direction (Ehrlein, 1980; Lechner-Doll et al. 1991; Kaske et al. 1994). Also, the drasticallyincreased proportion of large particles in the faeces of sheep with impaired reticular movements (compared with animals with undisturbed reticular contractions) indicates that the passage rate of particles depends primarily on their availability in front of the ROO during its opening, which is determined mainly by their flotation-sedimentation behaviour. If particle sedimentation in the RR is prevented experimentally, a high proportion of large particles can pass the ROO irrespective of their size (Kaske et al. 1992). The present study provides evidence that the velocity and the extent of the reticular contractions is responsible for the separation process of particles in the reticulum. Thereby, the characteristics of the reticular contractions affect the composition of forestomach contents which may, in turn, influence the rates of fluid and particle outflow from the reticulum (Faichney, 1986).

The reduction in feed intake in Expt 2 (weight in reticulum) compared with Expt 1 (control ad libitum) cannot be explained unequivocally. Feed intake is related in part to rumen fill (for review, see Forbes, 1995). Rumen fluid volumes were similar under both experimental conditions. Thus, the activation of tension receptors due to rumen fill and the weight in the reticulum (Grovum, 1979) may have inhibited feed intake. Second, a feeling of discomfort may be assumed due to the reduced appetite of the animals after introduction of the weight, as indicated by the markedly longer time spent feeding during Expt $2 \mathrm{~A}$ compared with Expt 3. Finally, the distension of the abomasum (Expt 2B) due to impaired passage of digesta from the abomasum into the duodenum may have had negative effects on feed intake. 
The higher rumen fluid volume in Expt 2 (weight in reticulum) compared with Expt 3 (pair fed control) can be explained by changed fluid inflow and outflow from the forestomach. It can be assumed that fluid inflow into the RR was higher during Expt 2 than during Expt 3. As water intake was similar (Table 3), the differences must be related to changes in saliva secretion. The weight in the reticulum may have stimulated reticular mechano-receptors which are known to influence saliva flow (Reid \& Titchen, 1988). Furthermore, the longer duration of feeding in Expt 2 than in Expt 3 would be expected to be accompanied by higher saliva production. Reduced fluid outflow in Expt 2 (weight in reticulum) compared with Expt 1 (control ad libitum), despite similar rumen fluid volumes, could be explained by a decreased size of the ROO during its opening, or a reduced pressure gradient between reticulum and omasum. Furthermore, changes in the composition of forestomach contents and disturbances of transpyloric flow could also influence reticular outflow (Faichney, 1986; Malbert \& Ruckebusch, 1989). It is not clear which of these factors contributed most to the reduced fluid outflow after introduction of the weight.

The disturbance of abomasal outflow after impairment of reticular movements (Expt 2B) could be at least partly caused by a changed consistency of reticular outflow because normal transpyloric digesta flow depends predominantly on hydrodynamic factors (Pröve \& Ehrlein, 1982; Russell \& Bass, 1985). Under normal physiological conditions, the DM content of reticular outflow is below $5 \%$ (Harmeyer \& Michalowski, 1981). Even small increases in the viscosity of abomasal contents can severely reduce abomasal outflow (Malbert \& Ruckebusch, 1988). The amount of fluid leaving the RR during each opening of the ROO decreased after introduction of the weight by $23 \%$ compared with Expt 1 (control ad libitum), despite a similar rumen fluid volume (Table 5). However, fluid outflow during Expt 3 was even less. Thus, an increased saliva flow together with the changes in the composition of particulate matter leaving the RR during Expt 2 may have influenced the viscosity of the digesta passing into the abomasum which, in turn, might have caused a reduction of transpyloric flow. Whether vago-vagal reflexes evoked by the presence of the weight in the reticulum may have influenced abomasal motility and emptying remains unclear. Furthermore, it cannot be established whether or not disturbances of abomasal outflow developed during Expt $2 \mathrm{~A}$ in the same way as during Expt $2 \mathrm{~B}$ since no investigation of the abomasum was carried out on day 11 of Expt $2 \mathrm{~A}$. However, as experimental conditions were identical it seems likely that the consequences of the weight should have been comparable. Thus, we assume that the more pronounced effect of the weight in Expt 2B in two animals has to be regarded as accidental.

\section{Pathophysiological implications}

Similar changes to those found in the sheep following introduction of the weight into the reticulum have been described for cows suffering from severe traumatic reticuloperitonitis. In these animals, foreign bodies picked up with the food penetrate the reticular wall and cause inflammatory adhesions between the reticulum and the abdominal wall; reticular movements are more or less impaired depending on the extent of the adhesions. Clinical findings are characterized by inappetence, rumen distension, unstratified rumen contents, an increased amount of large particles in the faeces and an enlarged impacted abomasum in several animals (Stöber \& Serrano, 1984; Rebhun et al. 1988; Blood \& Radostits, 1989; Braun et al. 1990). It was suggested by Hoflund (1940) that the syndrome develops as a consequence of lesions affecting the Nervus vagus caused by the foreign body; subsequently, the disease has been known in the clinical literature as 'vagus 
indigestion' or 'Hoflund's syndrome'. However, recently a clinical study demonstrated that the severity of the clinical symptoms was related directly to the extent of reticular immobilization; damage of the $N$. vagus was not found in any of the animals (Rehage et al. 1995). The present study reveals experimental evidence that impaired reticular movements alone can cause a disturbance of digesta passage.

\section{Conclusions}

The results emphasize that the normal sequence of reticular contractions is a precondition for physiological particle-separation processes in the RR. The strength of reticular movements directly affects the composition of reticular outflow. Changes in reticular outflow due to impaired reticular movements may cause disturbed abomasal outflow.

The authors gratefully acknowledge the assistance and advice of Mrs G. Becker, Professor Dr W. von Engelhardt, Dr P. Gregory and Dr J. Rehage. Studies were supported by a research grant from the Deutsche Forschungsgemeinschaft (DFG Ka 809/2-2). The Weende analysis of hay was carried out by the Department of Animal Nutrition, School of Veterinary Medicine, Hannover, Germany.

\section{REFERENCES}

Binnerts, W. T., van't Klooster, A. T. \& Frens, A. M. (1968). Soluble chromium indicator measured by atomic absorption in digestion experiments. Veterinary Record 87, 470.

Blood, D. C. \& Radostits, O. M. (1989). Vagus indigestion. Veterinary Medicine, 7th ed., 259-262. London: Baillière Tindall.

Braun, U., Steiner, A. \& Kaegi, B. (1990). Clinical, haematological and biochemical findings and the results of treatment in cattle with acute functional pyloric stenosis. Veterinary Record 126, 107-110.

Campling, R. C. \& Freer, M. (1962). The effect of specific gravity and size on the mean retention time of inert particles in the alimentary tract of the cow. British Journal of Nutrition 16, 507-518.

DesBordes, C. K. \& Welch, J. G. (1984). Influence of specific gravity on rumination and passage of indigestible particles. Journal of Animal Science 59, 471-475.

Ehle, F. R. \& Stern, M. D. (1986). Influence of particle size and density on particulate passage through alimentary tract of Holstein heifers. Journal of Dairy Science 69, 564-568.

Ehrlein, H. J. (1980). Forestomach motility in ruminants. Publications to Scientific Films. Series 5, Nr. 9/C 1328. Göttingen: Institute for Scientific Films.

Evans, E. W., Pearce, G. R., Burnett, J. \& Pillinger, S. L. (1973). Changes in some physical characteristics of the digesta in the reticulorumen of cows fed once daily. British Journal of Nutrition 29, 357-376.

Faichney, G. J. (1986). The kinetics of particulate matter in the rumen. In Control of Digestion and Metabolism in Ruminants, pp. 173-195 [L. P. Milligan, W. L. Grovum and A. Dobson, editors]. Englewood Cliffs, NJ: Prentice Hall.

Faichney, G. J. \& Gherardi, S. G. (1986). Relationships between organic matter digestibility, dry-matter intake and solute mean retention times in sheep given a ground and pelleted diet. Journal of Agricultural Science, Cambridge 106, 219-222.

Forbes, J. M. (1995). Physical limitation of feed intake in ruminants and its interactions with other factors affecting intake. In Ruminant Physiology: Digestion, Metabolism, Growth and Reproduction, pp. 217-232 [W. v. Engelhardt, S. Leonhard-Marek, G. Breves and D. Giesecke, editors]. Stuttgart: Ferdinand Enke Verlag.

Grovum, W. L. (1979). Factors affecting the voluntary intake of food by sheep. 2. The role of distension and tactile input from compartments of the stomach. British Journal of Nutrition 42, 425-436.

Harmeyer, J. \& Michalowski, T. (1981). A technique for the collection of reticular effluent of sheep. Journal of Veterinary Medicine 38A, 107-114.

Hoflund, S. (1940). Untersuchungen über Störungen der Funktion der Wiederkäuermägen durch Schädigungen des N. vagus verursacht (Investigations of dysfunctions of the ruminant stomach caused by damage to the vagus nerve). Svensk Veterinärtidskrift 45, Suppl.

Hooper, A. P. \& Welch, J. G. (1985). Change of functional specific gravity of forages in various solutions. Joumal of Dairy Science 68, 1652-1658. 
Hydén, J. E. (1955). A turbidimetric method of the determination of higher polyethylene glycols in biological material. Kungliga Lantbrukshögskolans Annaler 22, 139-145.

Jandel Corporation (1993). SIGMASTAT Version 1.01. San Rafael, CA: Jandel Corporation.

Kaske, M. \& Engelhardt, W. v. (1990). The effect of size and density on mean retention time of particles in the gastrointestinal tract of sheep. British Journal of Nutrition 63, 457-465.

Kaske, M., Hatiboglu, S. \& Engelhardt, W. v. (1992). The influence of density and size of particles on rumination and passage from the reticulo-rumen of sheep. British Journal of Nutrition 67, 235-244.

Kaske, M., Midasch, A. \& Rehage, J. (1994). Sonographic investigation of reticular contractions in healthy sheep, cows and goats and in cows with traumatic reticulo-peritonitis. Journal of Veterinary Medicine 41A, $748-756$.

Lechner-Doll, M., Kaske, M. \& Engelhardt, W. v. (1991). Factors affecting the mean retention time of particles in the forestomach of ruminants and camelids. In Physiological Aspects of Digestion and Metabolism in Ruminants, pp. 455-482 [T. Tsuda, Y. Sasaki and S. Kawashima, editors]. San Diego: Academic Press.

Malbert, C. H. \& Ruckebusch, Y. (1988). Gastroduodenal motor activity associated with gastric emptying rate in sheep. Journal of Physiology 401, 227-239.

Malbert, C. H. \& Ruckebusch, Y. (1989). Hyperphagia induced by pylorectomy in sheep. Physiology and Behavior 45, 495-499.

Mathison, G. W., Okine, E. K., Vaage, A. S., Kaske, M. \& Milligan, L. P. (1995). Current understanding of the contribution of the propulsive activities in the forestomach to the flow of digesta. In Ruminant Physiology: Digestion, Metabolism, Growth and Reproduction, pp. 2441 [W. v. Engelhardt, S. Leonhard-Marek, G. Breves and D. Giesecke, editors]. Stuttgart: Ferdinand Enke Verlag.

Mudgal, V. D., Dixon, R. M., Kennedy, P. M. \& Milligan, L. P. (1982). Effect of two intake levels on retention time of liquid, particle and microbial markers in the rumen of sheep. Journal of Animal Science 54, 10511055 .

Nehring, K. (1960). Agrikulturchemische Untersuchungsmethoden (Agricultural Chemical Examination Methods), 3rd ed. Hamburg and Berlin: P. Parey.

Nocek, J. E. \& Kohn, R. A. (1986). Initial particle form and size on change in functional specific gravity of alfalfa and timothy hay. Joumal of Dairy Science 70, 1850-1863.

Okine, E. K. \& Mathison, G. W. (1991). Reticular contraction attributes and passage of digesta from the ruminoreticulum in cattle fed roughage diets. Journal of Animal Science 69, 2177-2186.

Pröve, J. \& Ehrlein, H. J. (1982). Motor function of gastric antrum and pylorus for evacuation of low and high viscosity meals in dogs. Gut $23,150-156$.

Rebhun, W. C., Fubini, S. L. \& Timothy, T. K. (1988). Vagus indigestion in cattle: clinical features, causes, treatments, and long term follow up of 112 cases. Compendium of Continuing Education in Veterinary Practice 10, 387-391.

Rehage, J., Kaske, M., Stockhofe-Zurwieden, N. \& Yalcin, E. (1995). Evaluation of the pathogenesis of vagus indigestion in cows with traumatic reticuloperitonitis. Journal of the American Veterinary Medical Association 207, 1607-1611.

Reid, A. M. \& Titchen, D. A. (1988). Atropine-resistant secretory responses of the ovine parotid gland to refiex and direct parasympathetic stimulation. Quarterly Journal of Experimental Physiology 73, 413-424.

Russell, J. \& Bass, P. (1985). Canine gastric emptying of fiber meals: influence of meal viscosity and antroduodenal motility. American Journal of Physiology 249, G662-G667.

Siciliano-Jones, J. \& Murphy, M. R. (1986). Passage of inert particles varying in length and specific gravity through the postruminal digestive tract of steers. Journal of Dairy Science 69, 2304-2311.

Stöber, M. \& Serrano, S. (1984). Der grobsinnliche Kotbefund beim Rind (Gross findings in bovine faeces). Veterinärmedizinische Nachrichten 4, 353-371.

Sutherland, T. M. (1988). Particle separation in the forestomachs of sheep. In Aspects of Digestive Physiology in Ruminants, pp. 43-73 [A. Dobson, editor]. Ithaca: Cornell University Press.

Thielemans, M. F.; Francois, E., Bodart, C. \& Thewis, A. (1978). Mesure du transit gastrointestinal chez le porc à l'aide des radiolanthanides. Comparaison avec le mouton. (Gastrointestinal transit in the pig: measurement using radioactive lanthanides and comparison with sheep.) Annales de Biologie Animale, Biochimie, Biophysique 18, 237-247.

Ulyatt, M. J., Dellow, D. W., John, A., Reid, C. S. W. \& Waghorn, G. C. (1986). Contribution of chewing during eating and rumination to the clearance of digesta from the ruminoreticulum. In Control of Digestion and Metabolism in Ruminants, pp. 498-515 [L. P. Milligan, W. L. Grovum and A. Dobson, editors]. Englewood Cliffs, NJ: Prentice Hall.

Waghorn, G. C., Reid, C. S. W., Ulyatt, M. J. \& John, A. (1986). Feed comminution, particle composition and distribution between the four compartments of the stomach in sheep fed chaffed lucerne hay at two feeding frequencies and intake levels. Journal of Agricultural Science Cambridge 106, 287-296. 